\title{
Competency Analysis Customer Service Communication In Keeping Customer Loyalty
}

\section{Analisis Kompetensi Komunikasi Customer Service Dalam Menjaga Loyalitas Customer}

\author{
Arif Gunawan 1); Yanto ${ }^{2)}$; Fera Indasari ${ }^{2)}$ \\ 1, 2) Department of Communication, Faculty of Social Sciences, Universitas Dehasen \\ Bengkulu \\ Email: yantogoyo@unived.ac.id
}

How to Cite :

Gunawan, A., Yanto., Indasari, F. (2021). Competency Analysis Customer Service Communication In Keeping Customer Loyalty. Sengkuni Journal: Social Sciences and Humanities Vol. 2 No. 12021 page: 70-80. DOI: https://doi.org/10.37638/sengkuni.2.1.70-80

\section{ARTICLE HISTORY}

Received [03 May 2021]

Revised [06 June 2021]

Accepted [21 June 2021]

\section{KEYWORDS}

communication patterns,

customs, loyalty

This is an open access article under the $C C-B Y-S A$ license

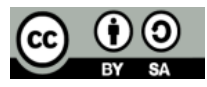

\section{ABSTRAK}

Dalam perkembangan informasi dan komunikasi PT Telkom selalu meningkatkan pelayanan kepada customer, maka dari itu Customer Service selalu memberikan yang terbaik untuk menjaga loyalitas customer oleh sebab itu penelitian ini, membahas tentang kompetensi komunikasi customer service dalam menjaga loyalitas customer pada produk PT. Telkom Indonesia cabang Kota Bengkulu. Tujuan penelitian ini adalah tujuan penelitian ini adalah untuk mengetahui dan menganalisis kompetensi komunikasi Customer Service dalam menjaga loyalitas customer dalam mencapai hasil yang dilakukan. Metode yang digunakan dalam penelitian ini adalah kulitatif deskriptif untuk memberikan gambaran yang jelas terhadap masalah penelitian.aspek berpedoman pada teori Murphy dan Hildebrandt (1991) yaitu dalam komunikasi terdapat tujuh aspek diantaranya Completeness, concisenes, Concretness, consideration, clarity, Courtesy, dan corretness dalam penelitian ini penulis hanya mengambil empat aspek diantaranya Completeness, Concisiness, Concretness, dan Courtesy. Alasannya, karena didalam empat aspek tersebut sudah dapat mewakili secara keseluruhan. Hasil penelitian di lapangan menunjukkan bahwa completeness atau kelengkapan informasi yang diberikan customer service telah dilaksanakan dengan baik, pimpinan customer service juga sudah melakukan pemantaun terhadap customer service dalam memberikan informasi secara lengkap dalam concisiness admin customer service telah diarahkan dengan baik untuk memberikan informasi yang jelas kepada customer pada aspek concretness admin customer service juga telah melaksanakan penyampaian informasi sesuai dengan prosedur yang ada sehingga customer dapat menerima informasi yang diberkan customer service. Courtesy telah dilaksanakan dengan baik seperti yang disampaikan pimpinan customer service bahwa melayani customer harus bersikap ramah, sopan dan santun dan bertata krama agar customer merasa kenyamanan ketika melakukan aktivitas yang berhubungan dengan produk PT. Telkom. 


\section{ABSTRACT}

In the development of information and communication PT Telkom always improves service to customers, therefore Customer Service always gives the best to maintain customer loyalty therefore this research, discussing the competence of customer service communication in maintaining customer loyalty in PT products. Telkom Indonesia branch of Bengkulu City. The purpose of this research is to know and analyze the competence of Customer Service communication in maintaining customer loyalty in achieving the results. The method used in this study is descriptive skin to give a clear picture of the research problem. aspects guided by murphy and hildebrandt theory (1991) namely in communication there are seven aspects including Completeness, concisenes, Concretness, consideration, clarity, Courtesy, and corretness in this study the author only took four aspects including Completeness, Concisiness, Concretness, and Courtesy. The reason is because in the four aspects it can already represent the whole. The results of research in the field showed that completeness or completeness of information provided by customer service has been implemented well, customer service leaders have also conducted monitoring of customer service in providing complete information in the concisiness admin customer service has been well directed to provide clear information to customers on aspects of customer service admin concretness has also carried out the delivery of information in accordance with procedures so that customers can receive information provided by customer service. Courtesy has been implemented well as conveyed by the head of customer service that serving customers must be friendly, polite and polite and manners so that customers feel comfortable when doing activities related to PT Telkom products.

\section{PENDAHULUAN}

Pada era globalisasi saat ini, telekomunikasi memiliki peranan sangat penting dan strategis dalam kehidupan manusia. Di Indonesia dengan jumlah penduduknya yang mencapai $261,890,900$ jiwa saat ini telah menjadi pasar potensial perkembangan digital. Potensi penggunaan telekomunikasi di Indonesia memang luar biasa. Dengan terus meningkatnya jumlah pengguna internet tentu mendorong pertumbuhan jumlah pengguna yang juga mengalami peningkatan yang pada awalnya berjumlah 88,1 juta pada tahun sebelumnya, angka tersebut kini telah naik menjadi 132,7 juta pengguna pada awal tahun 2017 di Indonesia. Seiring dengan perkembangan teknologi yang semakin pesat, masyakarat menjadi tertarik dan sadar akan pentingnya mendapatkan informasi untuk menggunakan internet. Tidak hanya sebagai kebutuhan aktivitas komunikasi dan entertainment semata, namun mulai beralih untuk kepentingan bisnis yang diantaranya terlihat dari banyaknya startup bermunculan dan semakin maraknya situs belanja online. Hal ini tentu membutuhkan support layanan telekomunikasi yang memumpuni, yang membuat semakin banyaknya industri telekomunikasi yang. berlomba-lomba karena memiliki potensi yang sangat besar, menurut studi dari lembaga penelitian ROA (Research On Asia) Group mengungkapkan perkembangan pasar industry telekomunikasi di Indonesia yang terus tumbuh pesat membuat persaingan semakin ketat, begitu pula di dunia industry perkembangan Teknologi Informasi dan 
Komunikasi (ICT) juga meningkat namun persaingan usaha, peningkatan kualitas produk, serta pelayanan yang excellent (unggul), menjadi tuntutan mutlak yang diinginkan konsumen pada mitra usaha agar tetap loyal pada kualitas produk yang ditawarkan.

Saat ini jumlah pengguna internet terus mengalami kenaikan. Dalam sebuah studi juga menyebutkan konsumsi internet telah mengalahkan konsumsi televisi, kebanyakan pengguna lebih sering mengakses internet melalui PC dan tablet dibandingkan melalui ponsel. Potensi pengguna internet tentu juga mendorong pertumbuhan bisnis di industri telekomunikasi indonesia, persaingan dalam memperebutkan pasar membuat perusahaan harus bekerja keras untuk dapat terus bertahan dalam jangka panjang. Kerja keras tersebut dapat berupa dengan menjaga loyalitas customer, karena loyalitas customer sangatlah penting bagi perusahaan untuk meningkatkan kinerja laba pada suatu perusahaan.Di samping itu penetapan untuk harga produk indihome dengan menggunakan penetapan harga relative dimana harga mengikuti gerak pesaing. Dengan harga itu pelanggan akan membayar lebih murah dari apa yang di dapatkan dengan beberapa produk indihome terbaru dari Telkom, dengan catatan apabila pelanggan menggunakan dengan maksimal. Namun pelanggan akan merasa membayar lebih mahal apabila pelanggan hanya menggunakan satu atau dua dari roduk indihome tersebut. Contohnya hanya menggunakan jaringan WIFI saja tanpa menggunakan TV kabel, kemudian menggunakan telpon dan jaringan WIFI dan menggunakan ketiga produk indihome. Berdasarkan observasi dan wawancara prapenelitian pada bulan Oktober 2020, pelayanan yang di sediakan PT. Telkom membuat customer merasa masih banyak mengeluh terhadap pelayanan Customer Service, hal ini diungkapkan dalam wawancara yang dilakukan oleh beberapa pelanggan pengguna layanan IndiHome Telkom.

Seperti yang diungkapkan oleh customer Indihome, saat ditanya apakah pelayanan PT. Telkom sudah baik dalam melayani keluhan pelanggan saat terjadi gangguan pada jaringan Indihome. Customer mengungkapkan, jika terjadi gangguan atau kerusakan jaringan biasanya customer langsung menghubungi Customer Service dan akan menunggu beberapa hari untuk perbaikan jaringan. Dalam pelayanan yang diberikan pihak PT. Telkom juga mendapat keluhan dari customer lain seperti yang diungkapkan oleh salah satu customer Indihome yang menyampaikan bahwa pada saat menghubungi ke nomor cell center pelanggan mengalami kesulitan nomor tersebut susah dihubungi sehingga membuat customer untuk datang langsung ke plaza telkom Bengkulu, pada saat customer melapor pihak plaza melayani costomer dengan tidak ramah sehingga membuat kecewa customer. Beberapa masalah tersebut akan membentuk sikap dari setiap customer tentang bagaimana mereka melihat permasalahan yang terjadi dengan bagaimana perusahaan memberikan respon. Jika dalam hal ini perusahaan bisa memberikan respon yang baik dan cepat secara tidak langsung customer akan merasa diperhatikan dan sebaliknya jika perusahaan lambat dalam merespon maka yang terjadi adalah munculnya opini negatif dari customer. Hal ini merupakan suatu kerugian yang besar bagi perusahaan jika peranan dari pelayanan tidak berjalan dengan semestinya.

PT. Telkom selalu memberikan yang terbaik untuk customer IndiHome Meskipun demikian apabila jaringan mengalami gangguan, gangguan ini bisa disebabkan oleh faktor cuaca, kabel putus dan bencana alam lainnya.Customer pasti akan lapor gangguan ke Customer Service, dengan adanya laporan bagaimana kita bisa menyampaikan pernyataan kepada customer atas gangguan tersebut, dapat dapat 
segera di atasi agar customer merasa puas sehingga tetap menjaga serta meningkatkan loyalitas customer. Seperti menurut Murphy dan Hildebrand (1991) ada 7 prinsip untuk melakukan komunikasi bisnis salah satunya Completeness dan conciseness dimana kita harus mengupayakan untuk bisa memberikan informasi selengkap mungkin kepada pihak yang membutuhkan. Karena informasi yang lengkap bisa membangun kepercayaan dan kepastian pada diri penerima informasi. Dan komunikasi juga dikemas dengan menggunakan kata-kata jelas, singkat, padat. Informasi utuh yang dikemukakan diatas harus disampaikan dalam kemasan yang jelas, singkat, dan padat. Dengan demikian, orang menjadi lebih mudah memahami apa yang kita komunikasikan. Komunikasi dalam bisnis sangatlah penting untuk kemajuan perusahaan.

\section{LANDASAN TEORI}

\section{Teori}

Menurut Purwanto (2006), Pengertian komunikasi bisnisadalah komunikasi yang digunakan dalam dunia bisnis yang mencakup berbagai macam bentuk komunikasi baik komunikasi verbal maupun nonverbal untuk mencapaitujuan tertentu. Pada dasarnya, terdapat 2 bentuk dasar komunikasi dalam dunia bisnis, yaitu komunikasi verbal dan nonverbal.

1. Komunikasi verbal merupakan salah satu bentuk komunikasi untuk menyampaikan pesan-pesan bisnis kepada pihak lain baik tertulis (written) maupun lisan (oral). Komunikasi verbal ini memiliki struktur teratur dan terorganisasi dengan baik, sehingga tujuan penyampaian pesan-pesan bisnis dapat tercapai dengan baik. Dalam dunia bisnis, beberapa contoh komunikasi verbal yakni: penyampaian pesan melalui surat, memo, teknologi komunikasi modern, rapat pimpinan, briefing kepada karyawan, wawancara kerja, dan presentasi, dan lain-lain.

2. Komunikasi Nonverbal. Berdasarkan teori antropologi, sebelum manusia menggunakan kata-kata, mereka telah menggunakan komunikasi nonverbal dalam gerakan-gerakan tubuh, bahasa tubuh (body language) sebagai alat untuk berkomunikasi dengan orang lain. Contoh sederhana komunikasi nonverbal : sikap seseorang yang secara spontan mengerutkan dahi, raut muka yang berubah, atau mata berkedip-kedip tanpa disengaja dan tak pernah direncanakan sebelumnya. Contoh lainnya, disaat Anda memperoleh kabar bahwa anak kesayangan anda satu-satunya mendapatkan penghargaan sebagai juara pertama dalam lomba tingkat nasional atau internasional! Bagaimana reaksi anda pada saat itu? Senang bercampur haru, Atau melihat ekspresi wajah rekan Anda yang menghadapi masalah, kesusahan maupun mereka yang senang atau gembira.

Menurut Katz (1994), Komunikasi Bisnis didefinisikan sebagai adanya pertukaran ide, pesan, dan konsep yang berkaitan dengan pencapaian serangkaian tujuan komersil. Komunikasi bisnis dapat diartikan juga sebagai komunikasi yang terjadi di dunia bisnis, dalam rangka mencapai tujuan dari suatu bisnis tersebut. Menurut Curtis (1992:6), Komunikasi bisnis adalah komunikasi dalam organisasi bisnis yang ditujukan untuk menyelesaikan masalah dan membuat keputusan. Menurutnya, semakin tinggi kedudukan seseorang dalam bisnis, ia akan semakin bergantung pada keahlian seseorang dalam membuat keputusan dan memecahkan masalah untuk suatu keberhasilan. Menurut Murphy dan Hildebrandt (1991), terdapat 7 prinsip yang harus dipegang saat melakukan komunikasi bisnis.Ketujuh prinsip tersebut dirangkum dalam akronim 7C. Prinsip tersebut adalah:

a. Completness, yang berarti kita harus mengupayakan untuk bisa memberikan informasi selengkap mungkin kepada pihak yang membutuhkan. Karena informasi 
yang lengkap bisa membangun kepercayaan dan kepastian pada diri penerima informasi. Orang biasanya mencari informasi karena dirinya sedang menghadapi ketidakpastian, adanya informasi yang lengkap akan membuat orang merasa memperoleh kepastian. Di samping itu, informasi yang tidak lengkap sering kali menimbulkan pertanyaan dan membuat komunikasi tidak efektif.

b. Conciseness, yang berarti komunikasi dikemas dengan menggunakan kata-kata jelas, singkat dan padat. Informasi utuh yang dikemukakan di atas harus disampaikan dalam kemasan yang jelas, singkat dan padat. Dengan demikian, orang menjadi mudah memahami apa yang kita komunikasikan. Tidak perlu mengernyitkan dahi untuk bisa memahami apa maksud informasi yang disampaikan.

c. Concretness, yang berarti pesan yang dikomunikasikan itu disusun secara spesifik dan konkret, bukan abstrak. Sering kita memperoleh informasi yang abstrak seperti tercermin dalam kalimat "perbaikan derajat kehidupan" atau "meningkatkan mutu". Sebenarnya kalimat tersebut bisa kita buat konkret. Perbaikan derajat kehidupan misalnya bisa kita buat konkret dengan kalimat "peningkatan penghasilan", "peningkatan taraf pendidikan" atau "peningkatan kesehatan".

d. Consideration, yang berarti pesan yang disampaikan mesti mempertimbangkan situasi penerima/komunikan. Kita sudah mempelajari variabel penerima tadi. Dalam menyampaikan informasi bisnis, penting bagi kita untuk mengetahui siapa komunikan atau penerima informasi itu. Kita pertimbangkan dengan baik siapa atau di mana komunikan kita.

e. Clarity, yang berarti pesan yang dikomunikasikan disusun dalam kalimat yang mudah dipahami komunikan (mendengar). Hal iniakan terkait dengan prinsip komunikasi sebagai proses berbagi. Informasi yang kita sampaikan mesti berorientasi pada penerima, sehingga kita membuat informasi itu sejelas mungkin sehingga bisa dipahami penerima. Informasi yang disampaikan sama sekali bukan untuk menunjukkan kecerdasan atau taraf pendidikan komunikatornya sehingga dipilih kata-kata yang menunjukkan taraf pendidikan komunikatornya dengan banyak menggunakan istilah atau jargon yang membingungkan penerima.

f. Courtesy, yang berarti sopan santun dan tata krama merupakan hal yang penting dalam berkomunikasi yang merupakan bentuk penghargaan kepada komunikan. Kesantunan merupakan bagian penting dari komunikasi. Dengan kesantunan orang akan menaruh penghargaan dan simpati pada diri kita. Kesantunan berbahasa, kesantunan sikap dan kesantunan perilaku merupakan bagian penting dan melekat pada tindakan komunikasi manusia.

g. Correctness, yang berarti pesan yang dikomunikasikan dibuat secara cermat. Untuk pesan tertulis misalnya dibuat dengan memperhatikan tata bahasa dan untuk pesan lisan disampaikan dengan memperhatikan komunikan. Kecermatan dan ketelitian akan membuat kita bisa mendeteksi sejak dini bila terjadi kekeliruan pada kemasan informasi yang kita persiapkan untuk kegiatan komunikasi bisnis kita.

\section{METODE PENELITIAN}

Pendekatan yang digunakan dalam penelitian ini adalah pendekatan kualitatif dengan jenis penelitian deskriptif. Pendekatan kualitatif yang dimaksud dalam penelitian ini adalah metode penelitian yang berlandaskan pada filsafat postpositivisme. Dengan menggunakan pendekatan kualitatif dengan jenis penelitian deskriptif peneliti dapat menjabarkan dan memperoleh pemahaman secara menyeluruh mengenai kompetensi 
komunikasi Customer Service dalam menjaga konsumen di PT. Telkom Indonesia Cabang Kota Bengkulu dianalisis dan dideskripsikan secara nonstatistik. Dengan menggunakan metode ini diharapkan agar penelitian yang dilakukan benar-benar mengenai sasaran dan dapat membuat pemahaman secara utuh.

Fokus dalam penelitian ini yaitu untuk mengetahui kompetensi komunikasi Customer Service dalam menjaga loyalitas customer PT. Telkom Indonesia Cabang Kota Bengkulu. Menurut Spradley (dalam Sugiyono 2019:275) Fokus penelitian yaitu merupakan domain tunggal atau beberapa domain yang terkait dari situasi sosial. Dimana fokus didasarkan pada tingkat barunya informasi yang akan diperoleh dari situasi sosial atau lapangan. Untuk menguraikan fokus penelitian tersebut maka penulis menggunakan aspek penelitian, agar peneliti dapat mengajukan pertanyaan-pertanyaan penelitian kepada informan.Dan mengarahkan peneliti untuk fokus pada lingkup dan aspek penelitian.Secara umum konsep komunikasi yang dikemukan oleh Murphy dan Hildebrandt (1991) diantaranya meliputi Completeness, concisenes, Concretness, consideration, clarity, Courtesy, dan corretness. Penelitian ini berfokus pada komunikasi pada Customer Service dalam meningkatkan loyalitas costumer pada produk PT. Telkom.Dalam penelitian ini penulis hanya mengambil empat aspek yaitu Completeness, Concisiness, Concretness, dan Courtesy. Alasannya, karena didalam empat aspek tersebut sudah dapat mewakili secara keseluruhan.

\section{HASIL DAN PEMBAHASAN}

\section{Hasil dan Pembahasan}

Hasil penelitian dan Pembahasan ini adalah untuk mengetahui kompetensi komunikasi Customer Service dalam menjaga loyalitas customer PT. Telkom Kota Bengkulu. Kompetensi komunikasi Customer Service tersebut meliputi Completeness, Concisenes, Concretness, dan Courtesy. Data hasil penelitian didapatkan berdasarkan data-data yang diperoleh peneliti langsung dari lapangan melalui proses teknik pengumpulan data. Adapun teknik pengumpulan data yang dilakukan peneliti yaitu observasi, wawancara dan dokumentasi.

Completeness adalah kelengkapan yang berarti kita harus mengupayakan untuk bisa memberikan informasi selengkap mungkin kepada pihak yang membutuhkan. Karena informasi yang lengkap bisa membangun kepercayaan dan kepastian pada diri penerima informasi. Orang biasanya mencari informasi karena dirinya sedang menghadapi ketidakpastian, adanya informasi yang lengkap akan membuat orang merasa memperoleh kepastian. Di samping itu, informasi yang tidak lengkap sering kali menimbulkan pertanyaan dan membuat komunikasi tidak efektif.

Completeness yang dilakukan di PT Telkom Bengkulu, Completeness meliputi tentang kelengkapan informasi yang diberikan Customer Service kepada customer. Data ini dikumpulkan melalui teknik pengumpulan data wawancara dan dokumentasi. Wawancara dilakukan kepada pimpinan Customer Service, Customer Servicedan customer Adapun dokumentasi berupa dokumen-dokumen pendukung pelaksanaan kegiatan Completeness.

Berdasarkan wawancara kepada pimpinan Customer Service yang bertindak sebagai fasilitator, pada aspek Completeness berkaitan pada kelengkapan pesan, fazliansyah menjelaskan dalam kelengkapan informasi yang disampaikan karyawan Customer Service sudah sesuai dengan kebutuhan-kebutuhan customer, saya selaku 
pimpinan terus memantau dalam proses penyampaian-penyampain informasi yang diberikan oleh Customer Service kepada customer, sebelum melakukan tugasnya kami selalu melakukan briefing untuk membahas apa-apa yang perlu disampaikan atau dibahas saran serta masukkan untuk tim customer servive supaya dalam pekerjaan tidak ada tekanan nantinya dan Customer Service lebih baik dalam melayani customer nantinya.

Dari pernyataan fazliansyah sebagai pimpinan customer service diatas penulis dapat mengambil keputusan, bahwa pimpinan customer service berperan dalam memantau customer service dalam menjalankan tugasnya, pimpinan customer selalu melakukan briefing dalam setiap melakukan tugasnya dalam kegiatan briefing pimpinan customerservice selalu bertanya apakah ada kendala yang dihadapi dalam melakukan pelayanan terhadap customer, pimpinan customer service selalu mengingatkan untuk memberikan semua informasi secara lengakap sesuai dengan kebutuhan-kebutuhan customer.

Berdasarkan hasil wawancara penulis dengan pimpinan customer service, maka dapat dipahami bahwa dalam mendapatkan keluhan-keluhan dari customer pihak customer service selalu memberikan masukan-masukan terhadap customer agar apapun keluhan dari customer dapat teratasi dan pihak customer service memberikan solusi terhadapa permasalahan-permasalah yang dialami oleh customer. Dalam melaksanakan kegiatan briefing, customer service juga membenarkan bahwa pimpinan customer service selalu menanyakan kepada kami setiap masalah yang dihadapi ketika melakukan pekerjaan agar permasalah tersebut dapat dipecahkan bersama-sama.

Hal senada juga disampaikan oleh salah satu customer PT. Telkom Kota Bengkulu yang menyatakan, saat kami menghubungi Customer Service sebelumnya kami diarahkan oleh pihak Telkom untuk menghubungi call center (0736) 147, online, facebook, twitter dan aplikasi my IndiHome apabila nanti kami mendapat masalah terkait produk telkom yang kami pakai, pada saat produk yang saya gunakan mengalami gangguan Customer Service langsung merespon dengan baik dan memberikan solusi kepada kami atas gangguan produk telkom yang saya dapatkan. Dari jawaban informan diatas penulis dapat mengambil kesimpulan, bahwa apabila customer mengalami gangguan, customer dapat menghubungi ke no cell center via online, fecebook, twitter dan aplikasi my Indihome, ketika mendapat laporan dari pihak customer, customer service pun langsung cepat tanggap dan merespon customer keluhan yang dilaporkan oleh customer dan membuat tiket gangguan atau perbaikan masalah yang dialami customer.

Berdasarkan hasil wawancara, customer berpendapat bahwa dalam melakukan pelayanan sudah dilakukan dengan kebutuhan customer dan hasil pengamatan dilapangan pelayanan dari Customer Service ke customer dilakukan dengan respon yang baik dan sudah sesuai dengan keinginan customer. Concisiness adalah sesuatu yang berarti komunikasi dikemas menggunakan kata-kata jelas, singkat dan padat. Informasi utuh yang dikemukakan di atas harus disampaikan dalam kemasan yang jelas, singkat dan padat. Dengan demikian, orang menjadi mudah memahami apa yang kita komunikasikan. Tidak perlu mengernyitkan dahi untuk bisa memahami apa maksud informasi yang disampaikan.

Berdasarkan wawancara langsung kepada pimpinan Customer Service mengenai aspek Concisiness, pimpinan Customer Service menyatakan, informasi yang disampaikan sudah dikemas dengan baik, karyawan saya admin Customer Service diarahkan untuk memberikan penjelasan yang terbaik kepada customer dan memberikan informasi yang jelas kepada customer agar customer memahami informasi yang diberikan, admin Customer Service juga diarahkan untuk memberikan penjelasan yang menarik guna menarik minat customer, seperti memberikan penjelasan mengenai 
kelebihan-kelebigha produk PT. Telkom, sehingga membuat customer lebih antusias untuk mendengarkan penjelasan yang diberikan.

Dari jawaban informan diatas penulis dapat mengambil kesimpulan dari pimpinan Costumer Service, bahwa informasi yang disampaikan kepada customer PT. Telkom telah di sampaikan sudah dikemas dengan baik dan telah diarahkan untuk memberikan informasi yang jelas sehingga dapat menarik guna menarik minat customer, dan membuat customer antusis dalam mendengarkan penjelasan yang diberikan.

Selanjutnya menurut informan kunci admin Customer Service karyawan PT. Telkom Kota Bengkulu mengungkapkan, Jelas, ketika menyampaikan informasi kami sebagai Customer Service mempunyai cara untuk selalu membuat informasi yang kami berikan kepada customer agar dapat dimengerti dengan jelas, informasi yang kami berikan sudah dikemas dengan dengan baik agar dapat diterima oleh pihak customer.

Dari jawaban informan dari admin Customer Service PT. Telkom diatas penulis dapat mengambil kesimpulan, bahwa informasi yang disampaikan kepada customer agar dapat dimengerti dengan jelas dan telah dikemas dengan baik agar dapat diterima oleh para customer.

Terkait dengan pernyataan yang diberikan admin Customer Service penulis juga melakukan wawancara kepada customer, customer menyampaikan, Customer Service dalam menyampaikan informasi sangat mudah dipahami oleh kami sebagai customer, customer selalu bersikap sopan dan ramah, apabila kami masih kurang terhadap informasi yang diberikan pihak Customer Service menanyakan kembali kepada kami sampai kami benar-benar memahami informasi yang diberikan.

Berdasarkan informasi yang yang telah dijelaskan oleh pimpinan Customer Service, admin Customer Service dan customer, bahwa pada aspek Concisiness, informasi yang diberikan sudah dikemas dengan baik sehingga memberikan dampak yang sangat positif demi kemajuan PT. Telkom, dalam menjalankan tugasnya Customer Service melakukan interaksi yang baik kepada customernya dan Customer Service memberikan informasi yang sudah dikemas dengan baik.

Concretness yang berarti pesan yang dikomunikasikan itu disusun secara spesifik dan konkret, bukan abstrak. Sering kita memperoleh informasi yang abstrak seperti tercermin dalam kalimat "perbaikan derajat kehidupan" atau " meningkatkan mutu". Sebenarnya kalimat tersebut bisa kita buat konkret. Perbaikan derajat kehidupan misalnya bisa kita buat konkret dengan penggunaan kalimat "peningkatan penghasilan", "peningkatan taraf pendidikan"atau" peningkatan kesehatan". Berdasarkan wawancara kepada pimpinan Customer Service mengenai menjaga loyalitas customer pimpinan customer melakukan pemantauan terhadap karyawan Customer Service terhadap komunikasi yang diberikan untuk menjaga loyalitas customer. Hal ini sesuai dengan hasil wawancara kepada pimpinan Customer Service yang menyatakan, komunikasi yang baik haruslah bisa disusun secara konkrit dan spesifik supaya yang mendengarkan informasi tersebut, mengenai kemampuan Customer Service dalam menyampaikan informasi saya rasa sudah sesuai dengan apa yang telah menjadi standar pelayanan kami yang mana costumer service wajib melaksanakan standar pelayanan yang ada supaya informasi yang diberikan konkrit dan spesifik.

Dari jawaban informan diatas penulis dapat mengambil kesimpulan, bahwa jelas melakukakn komunikasi yang baik haruslah bisa disusun dengan konkrit dan spesifik agar yang mendengarkan informasi dapat tertarik dan Costumer Service dalam menyampaikan informasi dirasakan sudah sesuai dengan apa yang telah menjadi standar pelayanan PT. Telkom, dimana Customer Service wajib melaksanakan standar pelayanan agar informasi yang diberikan konkrit dan spesifik.

Adapun hal senada juga disampaikan admin Customer Service dalam memberikan informasi yang konkrit dan spesifik, admin Customer Service mengungkapkan, Informasi 
yang kami berikan kepada customer sudah disampaikan secara konkrit dan spesifik, kami juga memiliki standar pelayan yang sudah ditetapkan agar informasi yang kami berikan dapat diterima dengan baik oleh pihak customer. Dari jawaban informan diatas penulis dapat mengambil kesimpulan, bahwa informasi yang diberikan kepada customer sudah disampaikan secara konkrit dan spesifik, kami juga memiliki standar pelayanan yang ditetapkan agar informasi yang diberikan dapat diterima.

Terkait dengan aspek Concretness dalam menjaga loyalitas konsumen pimpinan Customer Service, admin Customer Service dan customer menyampaikan informasi yang ada sudah spesik dan konkrit dan dilakukan sebagaimana prosedur pelayanan yang ada. Selain melakukan wawancara penulis juga melakukan obesrvasi langsung terhadap kegiatan Customer Service dalam memberikan informasi yang konkrit dan spesifik dimana customer service memberikan informasi dengan spesifik dan konkrit kepada customer. Courtesy yang berarti sopan santun dan tata krama merupakan hal yang penting dalam berkomunikasi yang merupakan bentuk penghargaan kepada komunikan. Kesantunan merupakan bagian penting dari komunikasi. Dengan kesantunan orang akan menaruh penghargaan dan simpati pada diri kita. Kesantunan berbahasa kesantunan sikap dan kesantunan perilaku merupakan bagian penting dan melekat pada tindakan komunikasi manusia.Data tentang aspek Courtesy dalam menjaga loyalitas pelanggan penulis lakukan melalui wawancara dan dokumentasi, wawancara dilakukan kepada pimpinan Customer Service, admin Customer Service dan customer.

Berdasarkan wawancara kepada pimpinan Customer Service mengenai aspek Courtesy, pimpinan Customer Service mengungkapkan, Melayani customer haruslah dengan sikap yang ramah, santun dan bertata krama agar customer merasakan kenyamanan ketika melakukan aktifitas yang berhubungan dengan PT. Telkom seperti melaporkan gangguan, pasang baru dan konsultasi masalah produk PT. Telkom.Customer Service mengawali komunikasi dengan memberikan salam kepada customer. Sikap ramah yang diperlihatkan customer dengan selalu menyapa setiap customer dan menawarkan bantuan kepada customer yang membutuhkan informasi dan menjawab semua pertanyaan serta complain oleh customer dengan sabar. Dari jawaban informan diatas penulis dapat mengambil kesimpulan, bahwa dalam melayani customer haruslah dengan sikap yang ramah, santun, dan bertata karma agar customer merasakan kenyaman ketika melakukan aktifitas yang berhubungan dengan PT. Telkom seperti mengawali komunikasi dengan ramah dan menyapa setiap customer dan menawarkan bantuan kepada customer yang membutuhkan informasi.

Dalam hal kesesuian standar pelayanan yang ada pimpinan Customer Service juga mengungkapkan, sesuai dalam dimensi pelayanan ada namanya yaitu kesopanan, menghargai, penuh pertimbangan, keramahan jadi sudah jelas bahwa kami dalam melakukan pelayanan harus bersikap sopan, karena kalau kita sopam kepada pelanggan, insyaallah perusahan kita akan semakin maju, dari jawaban informan diatas penulis dapat mengambil kesimpulan, bahwa dalam dimensi pelayan ada namanya yaitu kesopanan, menghargai, penuh pertimbangan, keramahan jadi jelas Customer Service PT. Telkom harus bersikap sopan kepada customer demi memajukan perusahaan.

Berdasarkan hasil pengumpulan data mengenai aspek Courtesy bahwa dalam menjaga loyalitas konsumen pihak Customer Service sudah memberikan pelayanan yang baik untuk customer, berdasarkan pengamatan dilapangan PT. telkom khususnya Customer Service sudah memberikan pelayanan dengan sikap sopan santun, bertata krama dan memberikan kepastian pengetahuan dengan baik berdasarkan standar pelayanan dan sudah berjalan dengan baik, karena sebagai perusahaan yang menyediakan jasa pelayanan maka harus bisa melayani customer dengan sikap sopan dan santun, emosi juga harus terkendali dan selalu bisa bersikap tenang dalam 
menghadapi pelanggan yang kurang menyenangkan dan hal tersebut sudah dijalankan oleh PT. Telkom dalam memberikan pelayanan kepada pelanggan.

\section{KESIMPULAN DAN SARAN}

\section{Kesimpulan}

Setelah melalui tahap penelitian dan pembahasan dari hasil penelitian, peneliti dapat memberikan kesimpulan dari hasil penelitian dan memberikan saran yang dapat digunakan dan bermanfaat bagi pihak yang terkait dalam penelitian ini Analisis Kompetensi Komunikasi Customer Service Dalam Menjaga Loyalitas Customer (Studi Pada Produk Indihome PT. Telkom Indonesia Cabang Kota Bengkulu). Dari hasil penelitian ini peneliti menggunakan 4 aspek penelitian. Aspek penelitian ini terdapat keterangan yang berupa penjelasan setiap aspek penelitian. Dari aspek pertama: Completeness yang dilaksanakan dalam menjaga loyalitas customer PT. Telkom Kota Bengkulu telah dilaksanakan dengan baik. Pimpinan Customer Service selalu melakukan pemantauan kepada karyawan Customer Service dalam melaksanakan tugas-tugasnya. Customer Service juga telah menyampaikan informasi kepada pihak customer dengan lengkap.

Kedua: dilihat dari aspek Concisiness dalam menjaga loyalitas customer PT. Telkom Kota Bengkulu telah dilaksanakan dengan baik. Menurut pimpinan Customer Service customer sudah diarahkan untuk menyampaikan penjelasan informasi yang terbaik dan memberikan informasi yang jelas kepada customer. Ketiga: dapat dilihat dari aspek Concretness dalam menjaga loyalitas customer PT. Telkom Kota Bengkulu sudah dilaksanakan dengan baik hal ini terlihat dari pihak Customer Service yang telah melaksanakan dengan sesuai prosedur yang ada sehingga customer dapat menerima informasi yang diberikan Customer Service. Aspek keempat Courtesy yang telah dilaksanakan dalam menjaga loyalitas PT. Telkom Kota Bengkulu telah dilaksanakan dengan baik. Seperti yang telah diungkapkan pimpinan Customer Service bahwa melayani customer bersikap ramah, sopan santun dan bertata krama agar customer merasa kenyamanan ketika melakukan aktivitas yang berhubungan dengan PT. Telkom.

\section{Saran}

1. Memberikan informasi selengkap mungkin dengan melakukan sosialisasi kepada customer dan memberikan informasi selengkap mungkin.

2. Pengaduan laporan menggunakan aplikasi mylndihome ataupun dengan brosurbrosur yang ada untuk dilakukan secara detail.

3. Meningkatkan mutu pelayanan, melalui pembinaan dan pengawasan karyawan. Selain itu bagi pelanggan, harus lebih aktif menanyakan bagaimana dan prosedur yang sebenarnya harus dilewati dalam pengaduan dalam layanan informasi pada produk PT. Telkom.

4. Selain itu bagi pelanggan, harus lebih aktif menanyakan bagaimana dan prosedur yang sebenarnya harus dilewati dalam pengaduan dalam layanan informasi pada produk PT. Telkom.

5. Bagi karyawan, semangat kerja harus meningkat, lebih cepat menanggapi keluhan-keluhan dan memberikan informasi, selalu percaya terhadap kemampuan 
diri sendiri dan bekerja dengan jujur demi kebaikan diri sendiri maupun kebaikan perusahaan PT Telkom Kota Bengkulu.

\section{DAFTAR PUSTAKA}

Bernard Katz. 1994. Komunikasi Bisnis. Jakarta: PT Ikrar Abadi.

Darmadi, Hamid. 2011. Metode Penelitian Pendidikan. Bandung: Alfabeta.

Griffin, Jil. 2003. Costomer Loyality. Menumbuhkan dan Mempertahankan Pelanggan. Jakarta: Penerbit Erlangga

Mukhtar. 2013. Metode praktis penelitian studi desktiptif. Jakarta:Press Group.

Murphy, Herta A. dan Herbert W. Hildeberamt. 1991. Effective Business Communication. New York:MCGrawa-Hill 